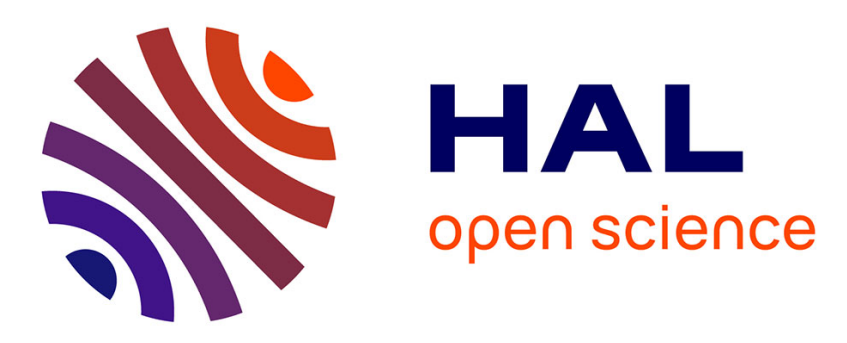

\title{
Legacy writing among the elderly: conceptual bases, dimensioning and a proposed scale for measuring motivations
}

Samuel Guillemot, Bertrand Urien

\section{- To cite this version:}

Samuel Guillemot, Bertrand Urien. Legacy writing among the elderly: conceptual bases, dimensioning and a proposed scale for measuring motivations. Recherche et Applications en Marketing (French Edition), 2010, 25 (english edition) (4), pp.25-43. 10.1177/205157071002500402 . hal-00587011

\section{HAL Id: hal-00587011 \\ https://hal.univ-brest.fr/hal-00587011}

Submitted on 19 Apr 2011

HAL is a multi-disciplinary open access archive for the deposit and dissemination of scientific research documents, whether they are published or not. The documents may come from teaching and research institutions in France or abroad, or from public or private research centers.
L'archive ouverte pluridisciplinaire HAL, est destinée au dépôt et à la diffusion de documents scientifiques de niveau recherche, publiés ou non, émanant des établissements d'enseignement et de recherche français ou étrangers, des laboratoires publics ou privés. 


\title{
Legacy writing among the elderly:
}

\section{conceptual bases, dimensioning and a proposed scale for}

\section{measuring motivations}

\author{
Authors manuscript, \\ published in "Recherche et Applications en Marketing English edition, 25, 4 (2010) 25-43" \\ Samuel Guillemot \\ PhD student \\ IAE Bretagne Occidentale Brest \\ ICI Laboratory (Information, Coordination, Incitations)
}

Bertrand Urien

Professor

IAE Bretagne Occidentale Brest

ICI Laboratory (Information, Coordination, Incitations)

The authors would like to thank the four anonymous reviewers whose comments contributed to improving this article, as well as Joël Brée, editor in chief, for his encouragements and suggestions.

They can be contacted at the following email addresses:

samuel.guillemot@univ-brest.fr; bertrand.urien@univ-brest.fr 
This article concerns a relatively unknown phenomenon in marketing that has become, however, extremely popular among older adults: legacy writing. While the writing of "egodocuments" has been the subject of many studies in gerontology, sociology and, above all, literature, research in marketing has yet to examine its specific components. The purpose of this article is to identify the concept of legacy writing and propose an initial scale to the academic and managerial community for measuring the motivations underlying this practice. Two sets of data collected with questionnaires (202 and 508 responses) have been used to develop and confirm the validity of a scale consisting in twenty items, divided into six dimensions (flattering the ego, mending the ego, being remembered, sharing, transmitting, and bearing witness). This research offers a contribution to the theoretical corpus on special objects and intergenerational transmission. It demonstrates that the meaning of a special object is not exclusively restricted to symbolic references that may be lost or denatured, but others that are explicit and inscribed at the very core of the object.

\section{KEYWORDS:}

Legacy writing, elderly, intergenerational transmission, identity 


\section{INTRODUCTION}

"Would you like to share your experience, let your passions live on a little longer, but have neither the time nor motivation to write? The biography writer is here to help you. $\mathrm{He}$ immerses himself in your life and emotions. A story emerges from your memories...The biography writer can help you write a book in your image" ${ }^{1}$. This excerpt from a French website, written by one of the many private biographers on the market, illustrates the current popular interest in memoirs and autobiographies. The trend seems particularly strong among the elderly if we consider the numerous advertisements designed to meet the need for remembrance and transmission published in media targeting seniors. Many older individuals have engaged in mentally constructing a coherent life story. While some do indeed transform these thoughts into action, most believe they will someday write their memoirs, without taking the idea any further. Since writing an autobiography is a long and difficult process, some people need a "ghost writer", while others merely require guidance. The market for socalled "biographical" services is highly diversified, rapidly developing and relatively unstructured. We can deplore numerous cases of abusive practices. For example, certain private writers have no qualms about charging $€ 8,000$ to "deliver" a biography, while others offer a similar service for only $€ 2,500^{2}$.

Indeed, from both a managerial and academic standpoint, this is a field that is relatively unknown in marketing research. While the writing of "ego-documents" (biographies, autobiographies, diaries, memoirs, etc.) (Gusdorf, 1991) has been the subject of many studies in gerontology, sociology and, above all, literature, research in marketing has yet to examine its specific components. This study concerns more specifically the experience of aging (Guiot, 2006). Subjective aging and the prospect of a limited future trigger coping mechanisms that can lead to a search for self-continuity and desires for self-preservation and/or extension. While marketing has examined self-extension, self-preservation and intergenerational transmission (Belk, 1988; Wallendorf and Arnould, 1988; Price, Arnould and Curasi, 2000; Curasi, 2006), these studies have mainly focused on the symbolic preservation and transmission of the self through "special or cherished" possessions. However, the significance of the possession transmitted is fragile and may be altered by the person who receives it (Epp and Arnould, 2006). Interestingly, legacy writing offers a way to circumvent the problem of symbolic meanings. Could it be an intergenerational practice aimed at transmitting important 
information to descendants? Or is it a means of identification that consists in highlighting and preserving a life rich in memories, experiences and meaning? More generally speaking, what are the motivations behind legacy writing? These are a few of the many questions raised by this field of investigation.

The purpose of this study is to identify the concept of legacy writing and propose an initial scale to the academic and managerial community for measuring the motivations underlying this practice. We will limit our investigations to the elderly, due to the frequency of the practice at this stage in life. In an initial phase, starting from an interdisciplinary review of the literature, we propose a brief socio-historical approach to the writing of "egodocuments", outlining how the elderly are particularly concerned by these practices and identifying the nature of the different motivations behind legacy writing. In a second phase, we will propose constructing and confirming the validity of a scale in order to measure the motivations of legacy writing by means of a double quantitative study. Finally, we will discuss the contributions, managerial implications and limitations of this study, as well as the avenues for future research it suggests.

\section{THEORETICAL FRAMEWORK}

After recapping its socio-historical aspects and defining the concept of legacy writing, we will examine its different internal motivations as identified in the source disciplines.

\section{Socio-historical aspects}

"Ego-documents" developed in the $18^{\text {th }}$ century, parallel to the process of "individualization". At that time, the privileged classes, who had access to writing, were less influenced by the dominant ideas of the Church and State and gradually became aware of the singularity of the individual. Little by little, the traditional worldview crumbled, collective obligations became weaker and access to a better education drew the individual into a world of values, standards and conflicting practices. In this "era of the individual", which encouraged everyone to perform as well as possible in every aspect of life while remaining "true to oneself", personal writings developed (Delory-Momberger, 2005). The narrative can help reconcile these multiple lives, by selecting and linking events. Generally, the distinction is made between fragmentary writings (such as a personal diary) and retrospective writing about the self (such as memoirs or autobiographies). In the first case, there is a search for 
meaning, which is highly prized among adolescents seeking their true identity, for example, while the second case involves construction of meaning from personal temporal events (Pineau and Le Grand, 1993; Carron, 2002). This second approach fits particularly well with the aging process. Indeed, when they reach retirement age, individuals often tend to think about their lives and what they have become (Erikson, 1959; Butler, 1963; CastelnuovoTedesco, 1980). This soul searching tends to shed new light on certain events and focus on important facts that the individual will seek to preserve and eventually transmit to others (Guiot, 2006). In addition, a common fear among the elderly is to see memories, experiences and other meanings accumulated over a lifetime dispersed after death (Curasi, 2006; Epp and Arnould, 2006).

\section{The motivations behind legacy writing}

Many disciplines are concerned with the practice of legacy writing. Sociology focuses on its role in identity construction (Delory-Momberger, 2005), while gerontology examines its specific influence on coping with aging (Argentin, 2006). The literary research stream devoted to the autobiography as a genre is concerned with analyzing narratives (Lejeune, 1975, 2005). A summary of this interdisciplinary review reveals six generic motivations:

\section{Flattering the ego}

The need for recognition is described as one of the pillars of personal writings. The narrative offers an opportunity for the writer to present himself to others (Madelénat, 2008), to highlight a positive career and emphasize the aspects of his life he deems worthy of interest such as his successes, skills, academic or professional achievements, etc. (Rioul, 2003). In the extreme, this approach can be perceived as a form of narcissistic gratification since the facts are selected and biased, offering a self-apology and even citing oneself as "a reference or example" (Miraux, 2005).

\section{Mending the ego}

In addition to flattering the author, the narrative can often be a means of evacuating discontentment. We must not overlook the liberating power of story telling, which allows the writer to express bottled up emotions and make a clean breast of things (Zarca, 2009). 
Similarly, legacy writing offers the opportunity to refute "wrongful" accusations (Hubier, 2003), to set the record straight, to formulate a correction or denial (May, 1979). Among "illustrious" writers, Rousseau was one of the first, in his time, to use his confessions to justify his conduct.

\section{Being remembered}

In the final years of life, legacy writing is a way of accepting the inevitable. Indeed, an in-depth analysis of his own experience allows the individual to portray himself as the hero of a unique and busy life (Tarman, 1988) and to take stock of what he wishes to leave behind, either in terms of a material estate or the experiences of a lifetime (Vercauteren and Hervy, 2003). From this standpoint, the life narrative is intended to outlive its author, as it allows the writer to impart what he wishes to be remembered for (Cristini and Ploton, 2009).

\section{Sharing}

In nursing homes for the elderly, legacy writing is highlighted as a means of communication, a vector for exchanges and sharing (Janvier, 2007), as it enables the creation of social ties between residents (Billé, 2006; Ribes et al., 2009), between residents and staff (Ross, 1990; Blanchard, 2006; Trueman and Parker, 2006) and even between residents and their own families (Argentin, 2006). Thus, by evoking his life story, the narrator can try to create a sort of intimacy with his readers.

\section{Transmitting}

Legacy writing is also described as a means of transmission that offers an opportunity to "hand on the torch", to situate one's life in a line of ancestors and present these long lost relatives to younger members of the family. It is also a way of playing a new social role, which was once reserved for "elders", of preparing the young generation for the future (Billé, 2002). 
Finally, legacy writing can be used to preserve certain information from one generation to another. The difference with the previous function, which is limited to the family circle, lies in the desire to make a broader contribution to the collective memory. Indeed, the narrator can, for example, describe an old-time profession that was lost due to new technologies or become the village historian (Lecarme and Lecarme-Tabone, 1999). Relating events in which one took part or to which one was a privileged witness is a way of representing a collective destiny (Zanone, 2006). Finally, legacy writing allows the narrator to contribute to "universal knowledge", to help tomorrow's sociologists, historians and researchers.

Thus, legacy writing can be considered a process of constructing meaning from personal temporal events. The story can focus - or not - on the narrator, be written for contemporaries or for posterity. It stems from deep motivations that we have identified during our review of the literature. Therefore, flattering the ego and bearing witness are proposed in the literary genre while mending the ego is highlighted in both the fields of literature and sociology. Gerontology emphasizes the importance of motivations for sharing, transmitting and being remembered.

CREATING AND VALIDATING A SCALE FOR MEASURING THE MOTIVATIONS BEHIND LEGACY WRITING

We started by a careful examination of the construct's field that we shall detail later on. This led us to select a mathematical model with reflexive indicators. We then went on to perform a series of steps, inspired by Churchill's paradigm (1979) and the remarks of Rossiter (2002) while adapting them to current analysis tools (structural equations). These are summarized in Table 1 and discussed in the following paragraphs.

<Insérer le Table 1 - The stages involved in constructing and validating the scale > 
For Rossiter (2002), the definition of a construct is based on three components: the object (legacy writing), the attribute (motivations) and the rater entities (people age 60 or older). In other words, we wanted to measure the motivations of individuals age 60 or over for legacy writing. More specifically, we proposed six latent constructs representing the different dimensions of these motivations (flattering the ego, mending the ego, being remembered, sharing, transmitting and bearing witness). In order to apprehend these constructs, we linked them to observable manifestations, for example, "I want to write so people can learn things about me that I am proud of" for the construct flattering the ego.

At this point, the crucial question is the relationship between these latent constructs and the variables measured. Indeed, we must bear in mind that an error in the direction of causality between a manifest variable and a latent construct during measurement model specification leads to an inappropriate purification procedure for the items (Diamantopoulos and Winklhofer, 2001; Jarvis, Mackenzie and Podsakoff, 2003; Crié, 2005). The articles of Jarvis, Mackenzie and Podsakoff (2003) and Podsakoff et al. (2003) are at the heart of the "reflexive vs. formative" debate. After reading recent contributions published in special issues of Psychological Methods $\left(2007 ; \mathrm{n}^{\circ} 12,2\right)$ and the Journal of Business Research $\left(2008 ; n^{\circ} 61\right.$ ), we decided to use a reflexive model (where the measured variables are effects of the constructs) for several reasons.

First, in following Howel, Breivik and Wilcox (2007a) and Bagozzi (2007), we estimate, unlike Podsakoff et al. (2003), that constructs are not formative or reflexive by nature and the design of a measurement model is more of an epistemological choice on the part of the researcher than a feature of the construct itself. We therefore place our study within a realist perspective (Howell, Breivik and Wilcox, 2007a), in that the mental construct under consideration exists outside its measurements. Furthermore, the use of reflexive indicators is advisable, considering the inherent limitations of formative constructs, formulated in an explicit manner in recent contributions (Diamantopoulos, 2006; Bollen, 2007; Franke, Preacher and Rigdon, 2008; Howel et al., 2007a; Diamantopoulos, Riefler and Roth, 2008). Among these, the fact that the error term does not represent a measurement error, but the surplus meaning of the construct that is not captured by its indicators, is a major drawback since, in practice, it is impossible to detect all the possible causes of a construct (Howel, Breivik and Wilcox, 2007b). The formative measures would also be subject to errors in interpretation (ibid). 
Secondly, Wilcox, Howell and Breivik (2008) suggest that the same list of items can be conceptualized in a formative or reflexive manner, depending on the instructions the researcher gives to the respondents. If the questions are formulated based on past actions ("I wrote my autobiography because..."), the indicators will a priori be formative of legacy writing (they are causes). On the other hand, if we evoke future events ("I would like to write an autobiography in order to..."), judgment is based on hypothetical actions and the indicators become reflections of the construct (Wilcox, Howell and Breivik, 2008). In the first case, we obtain an "objective" construct, while in the second case the reflexive indicators offer a construct that is subjective in nature, corresponding to the psychological constructs frequently used in studies of consumer behavior (Bollen, 2007).

\section{Creating and validating items}

We conducted a qualitative study with eight individuals who had written their life story, and eight others who were thinking of writing one. The qualitative study, which will not be developed here, enabled the emergence of the six motivations identified in the previous sections. We extracted a corpus of 96 verbatims characterizing these six types of motivation. Based on these verbatims and the literature, and taking into consideration the methodological points outlined above, we generated a list of 77 items representing reflections of each motivation.

To ensure face validity and reduce the initial list of items, these were submitted to a panel of five experts, all experienced researchers in consumer behavior and all familiar with the construction/manipulation of measurement scales. Following the procedure recommended by Jolibert and Jourdan (2006), the experts received a definition of the construct and its components. Each was asked to evaluate items as "highly", "sufficiently" or "not very" representative of the dimensions to which they were assigned. The experts also gave their opinion as to the clarity of the propositions. Therefore, certain items were reworded. Only items deemed "highly representative" by a majority were selected, except if they were considered "not very" representative by one of the experts. In the end, 36 items (or $46.75 \%$ of the initial number) were selected (see Appendix A1). 
Two data sets were collected. The first set was collected in the summer of 2009 and allowed us to purify indicators of the scale through exploratory principal components analyses using SPSS software. The second was collected in the autumn of the same year and was used for a confirmatory factor analysis with EQS software. The respondents were asked to what extent they agreed with statements listed in random order (Appendix A1) according to a 5point Likert scale ranging from "completely disagree" to "completely agree". The number of levels was set at five since older respondents are generally not comfortable with more complex response formats (Mezred et al., 2006). The questionnaires were distributed in situ, in places where people concerned by the study are most likely to congregate (retirement homes, clubs and associations for retirees, adult education courses, etc.). Considering the personal nature of certain questions, we preferred to use a self-administered questionnaire. In all, 710 useable responses were collected, 202 and 508 for the first and second data sets respectively. All the people questioned were over 60 years old. This threshold age was selected because many specialists in health, psychology and marketing agree that, along with retirement, it marks the beginning of "old age" for most people (Bresay, 2004; Fry, 1990; Guiot, 2006). The average age of the respondents was 71.28 (with a standard deviation of 8.6) for the first data set and 68.80 (with a standard deviation of 6.84) for the second. The two samples were composed, respectively, of $56 \%$ and $64 \%$ women. Levels of education were quite heterogeneous, indicating the social diversity of the samples (Appendix A2).

\section{Collecting the first data set and purifying the items}

After eliminating questionnaires with too much missing data and checking for the absence of outliers (Hair et al. 2008), the first data set produced 202 useable responses. Analysis of the correlations matrix of the 36 variables (not provided here) demonstrates that $94 \%$ of correlations are significant. Considering the level of intercorrelations, it is not surprising to obtain an MSA score of 0.89 . This means that the indicators have something in common and warrant use of a process to reduce information (Kaiser and Rice, 1974). A series of principal components analyses enabled us to identify a set of latent dimensions. Since the components were assumed to be correlated, we used an oblique oblimin rotation of the factor axes to facilitate interpretation. Only the factors with eigenvalues greater than 1 were 
selected. Finally, we deleted the items that did not cluster on any of the axes, or, on the contrary, saturated on several factors in a comparable way.

According to these criteria, 6 PCA were required to obtain a stable solution. At this stage, the 14 remaining items clustered around 4 factors. The items we had generated representing the dimensions transmitting and flattering the ego disappeared when the scale was purified (Appendix A1). For transmitting, the way the items were formulated was called into question. In order to generalize the statements and avoid special cases, we eliminated words pertaining to family life so as not to exclude respondents without children. However, the items formulated this way were too general and did not refer explicitly to values, roots and family history, aspects that are, according to the literature and our qualitative interviews, the ones most commonly transmitted. For the dimension flattering the ego, the definition submitted to the experts was questioned, since it insisted on its narcissistic character (to talk about the things I have done) rather than "recognition" which also plays a role (to show sides of myself others may not know). In light of these comments, we generated new items for these two components (9 in all). These items were validated by three new experts and we added them to the 14 others in order to collect another set of data (Appendix A1).

The second data set and the emergence of the factor structure

The second data set provided 508 useable responses. After checking for the absence of outliers, we again purified the items according to the rules defined in the previous phase. The analysis rendered 6 factors for 20 items. Only the latent roots of the first five factors were greater than 1. The scree test shows a first break after the fifth component (eigenvalue 1.07) and a second one, not quite as sharp, after the sixth (eigenvalue 0.93). We kept the sixth dimension as it is justified from a theoretical standpoint. Indeed, it also emerges in randomly drawn sub-samples. The final result is a scale consisting in 6 dimensions with 3 to 4 items each. The coefficients range from 0.79 for the dimension entitled sharing to 0.83 for bearing witness (Table 2).

< Insérer Table 2 - Final factor structure of the 20 items> 
At this point, our objective was to confirm the factor structure that had emerged through structural equation modeling. Confirmatory factor analysis (CFA) supposes a normal distribution of the data. Mardia's coefficient (G2, P) shows an absence of multivariate normality. It has a value of 85 (normalized estimate $=32$ ), much greater than the acceptable limit of 3 set by Bentler (2005). In fact, in the area of social sciences, data rarely has a normal distribution. The Satorra and Bentler statistic (1988), available under EQS software as "Robust methods", produces coefficients of significance corrected according to the intensity of non-normality.

The model tested consists in 6 latent constructs that are allowed to covary freely. This produced good indices of fit considering the degree of complexity and the number of observations. For a model with 20 items and 508 observations, the CFI should be greater than 0.92 and the RMSEA under a threshold of 0.07 (Hair et al., 2008). This is the case here: besides an $\chi^{2}$ of 340 for 155 degrees of freedom $(\mathrm{p}=0.00)$, the value of the CFI is 0.95 and that of the RMSEA is 0.05 (confidence interval of 90\%: [0.042-0.056]). Considering the high degree of correlations between the constructs, we believed it was important to test alternative models and more specifically the five-factor model that had emerged in the beginning. The indices of fit for the latter are under commonly accepted thresholds and consequently lower than those for the 6-factor model $\left(\chi^{2}=557\right.$; dof $=160(\mathrm{p}=0.00)$; CFI $=0.90$; RMSEA $=$ 0.07). Similarly, several other models were tested, for example the unidimensional model ( $\chi^{2}$ $=1194$; dof $=170(\mathrm{p}=0.00)$; CFI $=0.74$; RMSEA $=0.11)$, but none produced fit indices as satisfactory as the six-dimensional one. Therefore, the six dimension factor structure produced the best results and was finally selected.

\section{Reliability, convergent and discriminant validities of the measurement model}

In this phase we will examine the psychometric qualities of the instrument by testing its reliability and convergent and discriminant validities. Face validity has already been confirmed as the items were selected by experts. The nomological validity will be examined in the following section. 
Reliability is confirmed when all the indicators measure the same construct in a more or less equal manner. Here this is ensured by the coefficients for Jöreskog's rhô, which are all greater than 0.7 (Table 3), a commonly accepted threshold (Fornell and Larker, 1981).

The convergent validity corresponds to the capacity of a measure to provide results close to other measures of the same trait. This is confirmed when: (1) the z-test associated with each factor contribution is greater than 1.96 (a significant link between a latent construct and its indicators) and (2) each indicator shares more variance with its construct than with its error term (Steenkamp and Van Trijp, 1991). In reality, this condition is fulfilled if the average variance extracted $\left(\rho_{\mathrm{vc}}\right)$ for each dimension is greater than 0.5. All the latent constructs meet these two conditions (Table 3 ).

\section{<Insérer Table 3 - Evaluation of reliability and convergent validity >}

The discriminant validity is ensured when two theoretically different constructs are clearly distinguished empirically. Thus, the correlations between the two constructs must be less than the square root of their $\rho_{\mathrm{vc}}$, which is the case here (Table 4). It should be noted, however, that certain correlations are high, for example between the components of mending the ego and being remembered (0.70). Nevertheless, the indicators within a single dimension share more variance with each other than with those of another dimension.

<Insérer Table 4 - Evaluation of discriminant validity and correlations between

\section{constructs>}

Second-order factor analysis and nomological validity

Since the correlations between constructs were all important and significant (from 0.50 and 0.70), we performed an exploratory second-order factor analysis. This caused a single higher order factor to emerge. The confirmatory analysis produced good indices of fit $\left(\chi^{2}=\right.$ $381 ;$ dof $=164(\mathrm{p}=0.00) ; \mathrm{CFI}=0.95 ;$ RMSEA $=0.05)$. The standardized loadings between the first-order constructs and the higher order factor are all significant and greater than 0.7. The model with a single second order factor was therefore accepted (Table 5). This means that the six motivations share a common concept, which would be an overall motivation to 
write one's life story. From a theoretical standpoint, this appears to fit with a hierarchical conception of motivation (Vallerand, 1997, 2000; Vallerand and Miquelon, 2009). The overall motivation behind legacy writing would be expressed in the form of six contextual motivations (bearing witness, transmitting, etc). Once again, we followed Howel, Breivik and Wilcox (2007a) in considering that this global motivation exists independently from its measure. The first order latent constructs, representing the different motivations, therefore constitute reflections of the second order factor.

\section{<Insérer Table 5 - Second-order factor analysis>}

As for nomological validity, it is ensured if we can observe, empirically, that an individual with these motivations for legacy writing does intend to write his life story. Indeed, it aims to confirm the definition of the construct by studying the correlations between the construct and other manifestations that are intrinsically attached to it in a quasi tautological way (Jolibert and Jourdan, 2006). The intention of writing one's life story has been operationalized using a single item scale. This is sufficient if the construct is conceptualized in a concrete and unique manner by the respondent (Rossiter, 2002; Bergkvist and Rossiter, 2008), which is the case of behavioral intentions (Jarvis et al., 2004). With the help of the semi-structured interviews we conducted (not dealt with here), we were able to distinguish different specific stages in commitment to writing a life story: not interested, interested but does not plan to write a life story, plans to write a life story one day, extremely interested in getting started or already involved in the writing process These modalities were proposed to the respondents during the quantitative study. In order to avoid an artificial correlation linked to the order in which the questions were administered, two other scales were inserted between the items measuring motivations for legacy writing and the intention to write a life story. In addition, while the scale thus designed is not metric, the data can be estimated within a structural equations model as the modalities reflect an increasing degree of commitment (Byrne, 2006). In such a case, estimation using the maximum likelihood method with SatorraBentler's adjusted indices (1988) guarantees reliable results (DiStefano, 2002; Bentler, 2005).

The results obtained indicate a significant correlation between the two constructs $(\mathrm{r}=$ 0.50 ; z-test $=10.16)$, thus confirming the nomological validity of the scale. 
RESEARCH

\section{Contributions}

The aim of this study was to identify the concept of legacy writing, define its dimensions and propose a scale for measuring its underlying motivations (Appendix A3). To our knowledge, this is the first theoretical and empirical study on the subject in terms of consumer behavior. Starting from a review of the literature and two quantitative data sets, we created a reliable and valid scale for measuring the motivations behind legacy writing among the elderly. The scale consists in 20 items, divided among six dimensions (flattering the ego, mending the ego, being remembered, sharing, transmitting and bearing witness).

This scale represents a first step towards understanding the concept of legacy writing. It will help provide an empirical understanding of the relationship between motivations underlying this practice and other variables within the concept's nomological network. Furthermore, this study enriches our understanding of self-extension and self-preservation "tactics" (Price, Arnould and Curasi, 2000) and intergenerational transmission strategies among the elderly (Curasi, Price and Arnould, 2004; Curasi, 2006). Legacy writing, using any media (a book, CD, etc.), thus appears to be a new form of "special object" whose symbolic part is lost for the benefit of a specific function. We should note that "special" or "precious" objects (wedding rings, grandpa's pen, etc.) are "vehicles" for family and individual histories (Curasi, Price and Arnould, 2004; Bergadaà and Urien, 2008) and possess a certain number of functions similar to those we have identified for legacy writing: a form of recognition, a souvenir of important moments in life, an eye witness account of exceptional events, a record of specific skills and abilities (Price, Arnould and Curasi, 2000). It also has a therapeutic value and provides, in particular, a point of reference and stability (Wapner, Dermick and Redondo, 1990). Finally, it can be a means for transmitting individual and family values. When it is offered as a gift or left to a person who is able to preserve its meaning, it constitutes a means of being remembered (Price, Arnould and Curasi, 2000) and is a form of intergenerational transmission (Goldberg, 2009). Yet, while a life story can be considered a special object, it remains quite specific. Transmission of special object is often considered a symbolic transmission of the self. The information transmitted is therefore limited to fleeting memories generated by the object in question once its owner has passed. However, a life story goes much further by offering the transmission of an explicit, more or less faithful and 
sometimes idealized, summary of the self. The explicit nature of the information contained in a life story enables it to play a major role in the transmission of intergenerational memory and offers a partial remedy to the fragile meaning attached to objects, as emphasized in our introduction (Epp and Arnould, 2006).

\section{Managerial implications}

While biographical services remains a niche market, the potential for development is nevertheless real. Indeed, while collecting the second data set (508 individuals), $12.8 \%$ of the respondents had already written a life story or were currently writing their memoirs. In addition, more than $50 \%$ had already thought about it, but were discouraged by the difficulty of the task, which is undoubtedly why $42 \%$ stated they were interested in some form of training ( $18 \%$ in "co-production" services $\left.{ }^{3}\right)$. In this case, marketing can play a fundamental role. If it succeeds in motivating some of the individuals interested in legacy writing to get started, our field will have played an important role in transmission of intergenerational memory. Along these lines, certain anthropologists, while observing growing indifference to rituals surrounding death, predict the creation of a new type of necropolis. Mnemonic monuments (Larcher, 1971) would be used to conserve the memory of the deceased rather than their bodies or physical remains. Here there seems to be a potential for new services targeting seniors.

Furthermore, by identifying the different motivations behind legacy writing, service providers will be able to segment their offers since a person who wants, above all, to transmit his family history does not have the same needs or expectations as someone who wants mainly to relate his experience of racism, for example. Fundamentally, training services (workshops, coaching, etc.) are suitable when the process is as important as the result, for example, when the narrative is guided by a desire to mend the ego and the writing process is a form of "healing". Conversely, "co-production" services are more suitable when the narrative is more important than the writing process. For example, when the autobiography addresses the needs of a community (transmitting and bearing witness) the underlying idea is to serve others, by whatever means.

\footnotetext{
3 Private biographers. We use the term "co-production" here because the consumer supplies the raw material (memories) and the service provider contributes his writing skills.
} 
There are obvious ethical questions involved that need to be taken into consideration. We have already pointed out, at the beginning of this article, prices for similar services can vary considerably. It is important to bear in mind that managerial ethics are based on moral values, compliance with laws, codes of business conduct and personal responsibility (Katz and Marshall, 2003; Bergadaà, 2004; Urien and Guiot, 2007). This scale should be used with caution, in an effort to meet the needs of elderly consumers, not to take advantage of them.

\section{Limitations and perspectives for future research}

Several limitations can be raised concerning this study. One concerns the external validity of the scale. Its validity was confirmed using a sample of elderly persons. Our results can be considered a first step as the scale must be compared against other representative data for the general population in order to increase its validity. Our second data set was indeed mostly made up of people attending continuing education courses at "Universités $d u$ Temps Libre“, who have a higher level of education than the general French population. We can also question whether the French biographical model can be transferred to other cultures. Each culture has its own representations of the self, with its own concepts for conceiving of and expressing personal, family and cultural experiences. According to Roche (2007), for example, the autobiography exists in North African countries, but often contains a mix of real and fictional events and poetry. From a more general standpoint, an extension of this study internationally, to include other cultures, could examine both the stability of the different motivations behind legacy writing identified here and the types of biographical services available.

In this study we have not examined cohort effects (Meredith and Schewe, 1994; Zemke, Raines and Filipczak, 2000). The socio-historical events that take place during the years when important life choices are made (age 15 to 25 ) shape the attitudes and behaviors of a given generation (Préel, 2000). Thus, the 1920-1930 cohort, which took part in and survived WW2, does not have the same story to tell and transmit as the 1945-1955 cohort, which grew up in a booming economy (Lalive d'Épinay and Cavalli, 2009). However, we believe that generational differences would not affect motivations, but rather the content of the story itself. This point remains to be clarified.

Furthermore, we did not examine the reasons people prefer written over oral transmission (Martin Sanchez, 2003). Thus, our "functionalist" approach to life stories - and its methodological dimension, which consisted in questioning people about their motivations 
for writing an autobiography - can be called into question. This approach privileges the conscious and intentional motivations behind legacy writing and does not focus on the meaning individuals attribute to their own behavior. A comprehensive approach to legacy writing therefore offers an interesting avenue for future research.

It would be interesting now to examine other variables that could affect biographical behavior such as feelings of self-efficacy (Bandura, 1986), generativity (McAdams and de St. Aubin, 1992; Urien and Kilbourne, 2007, 2011), or even reminiscence (Webster, 1993; Haber, 2006). Price, Arnould and Curasi (2000), as well as Curasi, Price and Arnould (2004), present transmission of special objects as a desire for self-preservation after death, a form of symbolic immortality. However, these authors do not make any distinctions in their presentation of the final moment (Urien, 2003). Yet, there are different attitudes toward personal death that generate either anxiety or acceptance. More specifically, Florian and Kravetz (1983) and Florian and Snowden (1989) present a multidimensional model of fear of personal death (fear of loss of self-fulfillment, fear of self-annihilation, fear of loss of social identity, fear of consequences of death to family and friends, fear of transcendental consequences, fear of punishment in the hereafter). An important research question would concern the impact of the type of attitude towards personal death on the nature and intensity of motivations to write a life story.

Another research topic would consist in comparing the biographical tendencies of different generations. Thus, the same type of approach could be envisaged in order to understand the quest for identity among adolescents through personal diaries and blogs, or to understand social networks such as Facebook. Self-production as a relationship technique (Cardon and Delaunay-Teterel, 2006) is a highly contemporary field of investigation. The field of application for biographical services could also be expanded to, for example, business biographies (d'Almeida and Merran-Ifrah, 2005) or more generally corporate histories, as can be observed in this excerpt from a major regional newspaper ${ }^{4}$ : "In a time of crisis, History is a safe investment. As a biographer, Hélène's books are true corporate sagas. In the region, many entrepreneurs use her services."

$4 \quad$ Ouest-France, November 2008. 
d'Almeida N. et Merran-Ifrah S. (2005), Le récit patronal, la tentation autobiographique, Revue Française de Gestion, 159, 109-122.

Argentin L. (2006), Parler de son temps: récits de vie et ateliers d'écriture, Soins Gérontologie, 57, 38-42.

Bagozzi R.P. (2007), On the meaning of formative measurement and how it differs from reflective measurement: comment on Howell, Breivik, and Wilcox (2007), Psychological Methods, 12, 2, 229-237.

Bandura A. (1986), Social foundations of thought and action: a social cognitive theory, Englewood Cliffs, NJ, Prentice-Hall.

Barreau A. (1992), Quelle mort pour demain ? Essai d'anthropologie prospective, Paris, L'Harmattan.

Belk R. (1988), Possessions and the extended self, Journal of Consumer Research, 15, 2, 139168.

Bentler P.M. (2005), EQS 6 structural equations program manual, Encino, CA: Multivariate Software (www.mvsoft.com).

Bergadàa M. (2004), Évolution de l'épistémè économique et sociale : proposition d'un cadre de morale, de déontologie, d'éthique et de responsabilité pour le marketer, Recherche et Applications en Marketing, 19, 1, 55-72.

Bergadaà M. et Urien B. (2008), La personne âgée : son attitude face à l'idée de mort, le cadre temporel de son action et son sens de l'objet, « Rupture, finitude, mort et management » Seconde conférence internationale sur le temps de Brest, 25-26 juin.

Bergkvist L. et Rossiter J.R. (2008), Comparaison des validités prédictives des mesures d'un même construit des échelles mono-item et des échelles multi-items, Recherche et Applications en Marketing, 23, 1, 81-96.

Billé M. (2002), À quoi servent les grands-parents ? Des grands-parents pour introduire au « sacré », Dialogue, 158, 3-10.

Billé M. (2006), Le lien social au cour de la prévention, Le traitement social de la vieillesse, La gérontologie en actes, Paris, L'Harmattan, 71-84.

Blanchard F. (2006), Rejouer les évènements de vie du grand âge, La Revue Francophone de Gériatrie et de Gérontologie, 123, 128-132. 
Bollen K.A. (2007), Interpretational confounding is due to misspecification, not to type of indicator: comment on Howell, Breivik and Wilcox, Psychological Methods, 12, 2, 219228.

Bresay C. (2004), Vieillir, Études sur la Mort. Thanatologie, 126, 37-42.

Butler R.N. (1963), The Life Review: an interpretation of reminiscence in the age, Psychiatry, $26,65-75$.

Byrne B.M. (2006), Structural equation modeling with EQS: basic concepts, applications, and programming, $2^{\mathrm{e}}$ édition, Londres, Lawrence Erlbraum associates Publishers.

Cardon D. et Delaunay-Teterel H. (2006), La production de soi comme technique relationnelle. Un essai de typologie des blogs par leurs publics, Réseaux, 24, 3, 138, 15 71

Carron J.-P. (2002), Écriture et identité, pour une poétique de l'autobiographie, Bruxelles, Ousia.

Castelnuovo-Tedesco P. (1980), Reminiscence and nostalgia: the pleasure and pain of remembering, in S.I. Greenspan et G.H. Pollock (coord.), The course of life: psychoanalytic contributions toward understanding personality development (Vol III: Adulthood and the aging process), Washington DC: US Department of Health and Human Services, 115-127.

Churchill G.A. (1979), A paradigm for developing better measures of marketing constructs, Journal of Marketing Research, 16, 1, 64-73.

Crié D. (2005), De l'usage des modèles de mesure réflexifs ou formatifs dans les modèles d'équations structurelles, Recherche et Applications en Marketing, 20, 2, 5-27.

Cristini C. et Ploton L. (2009), Mémoire et autobiographie, Gérontologie et Société, 130, 7595.

Curasi C.F. (2006), Maybe it is your father's oldsmobile: the construction and preservation of family identity through the transfer of possessions, Advances in Consumer Research, $33,82-86$.

Curasi C.F., Price L.L. et Arnould E.J. (2004), How individuals' cherished possessions become families' inalienable wealth, Journal of Consumer Research, 31, 3, 609-623.

Delory-Momberger C. (2005), Histoire de vie et recherche biographique en éducation, Paris, Economica.

Diamantopoulos A. (2006), The error term in formative measurement models: interpretation and modelling implication, Journal of Modelling in Management, 1, 7-17. 
Diamantopoulos A., Riefler P. et Roth K.P. (2008), Advancing formative measurement models, Journal of Business Research, 61, 1203-1218.

Diamantopoulos A. et Winklhofer H.M. (2001), Index construction with formative indicators: an alternative to scale development, Journal of Marketing Research, 38, 2 269-277.

DiStefano C. (2002), The impact of categorization with confirmatory factor analysis, Structural Equation Modeling: A multidisciplinary Journal, 9, 327-346.

Epp A.M. et Arnould E.J. (2006), Enacting the family legacy: how family themes influence consumption behaviour, Advances in Consumer Research, 33, 82-86.

Erikson E.H. (1959), Identity and the life cycle: selected papers, Psychological Issues, 1, 50100 .

Florian V. et Kravetz S (1983), Fear of personal death: attribution, structure, and relation to religious belief, Journal of Personality and Social Psychology, 44, 3, 600-607.

Florian V. et Snowden L.R. (1989), Fear of personal death and positive life regard, Journal of Cross-Cultural Psychology, 20, 1, 64-79.

Fornell C. et Larker D.F. (1981), Evaluating structural equations models with unobservable variable and measurement error, Journal of Marketing Research, 18, 1, 39-50.

Franke G.R. , Preacher K.J. et Rigdon E.E. (2008), Proportional structural effects of formative indicators, Journal of Business Research, 61, 1229-1237.

Fry M.L. (1990), Cross-cultural comparisons of aging, in K.F. Ferraro (coord.), Gerontology: perspectives and issues, New York, NY, Springer Publishing Co, 129-146.

Goldberg A. (2009), Réaliser une boîte à souvenir, Gérontologie et Société, 130, 155-170.

Guiot D. (2006), Un cadre d'analyse du processus de vieillissement et de son influence sur le comportement d'achat du consommateur âgé, Recherche et Applications en Marketing, $27,1,57-79$.

Gusdorf G. (1991), Lignes de vie - Les écritures du moi (tome 1), Paris, Odile Jacob.

Haber D. (2006), Life Review: implantation, theory, research and therapy, International Journal of Aging and Human Development, 63, 2, 153-171.

Hair J.F. Jr., Black W.C., Babin J.B., Anderson R.E. et Tatham R.L. (2008), Multivariate data analysis, 7e édition, Pearson, Prentice Hall.

Howell R.D., Breivik E. et Wilcox J.B. (2007a), Reconsidering formative measurement, Psychological Methods, 12, 2, 205-218.

Howell R.D., Breivik E. et Wilcox J.B. (2007b), Is formative measurement really measurement? Reply to Bollen (2007) and Bagozzi (2007), Psychological Methods, 12, $2,238-245$. 
Hubier S. (2003), Littératures intimes: les expressions du moi, de l'autobiographie à l'autofiction, Paris, Armand Colin.

Janvier M. (2007), Atelier d'écriture et personnes âgées, Aux vendanges de la vie, Lyon, Chronique Sociale.

Jarvis B.C., Mackenzie S.B. et Podsakoff P.M. (2003), Critical review of construct indicators and measurement model misspecification in marketing and consumer research, Journal of Consumer Research, 30, 2, 199-218.

Jolibert A. et Jourdan P. (2006), Marketing research, Méthodes de recherche et d'études en marketing, Paris, Dunod.

Kaiser H. et Rice J. (1974), «Little Jiffy Mark 4 », Educational and Psychology Measurement, 34, 111-117.

Katz S. et Marshall B.(2003), New sex for old: lifestyle, consumerism, and the ethics of aging well, Journal of Aging Studies, 17, 3-16.

Lalive d'Épinay C. et Cavalli S. (2009), Mémoire de l'histoire et appartenance générationnelle des personnes âgées, Gérontologie et Société, 130, 127-144.

Larcher H. (1971), Mnémothèques pour l'an 2000, Bulletin de la Société de Thanatologie, 17, $1-17$.

Lecarme J. et Lecarme-Tabone E. (1999), L'autobiographie, $2^{\mathrm{e}}$ édition, Paris, Armand Colin.

Lejeune P. (1975), Le pacte autobiographique, Paris, Le Seuil.

Lejeune P. (2005), Signes de vie : Le pacte autobiographique 2, Paris, Le Seuil.

Madelénat D. (2008), Moi, biographe : m’as-tu vu ?, Revue de Littérature Comparée, 325, 95-108

Martin Sanchez M-O. (2003), Discours oraux, discours écrits, les seniors et l'écriture de soi, Gérontologie et Société, 106, 97-109.

May G. (1979), L'autobiographie, Paris, PUF.

McAdams D.P. et de St. Aubin E. (1992), A theory of generativity and its assessment through self-report, behavioural acts, and narrative themes in autobiography, Journal of Personality and Social Psychology, 62, 1003-1015.

Meredith G. et Schewe C.D. (1994), Cohort effects, Marketing Management, 3, 3-25.

Mezred D., Petigenêt V., Fort I., Blaison C. et Gana K. (2006), La réminiscence : concept, fonctions et mesures. Adaptation française de la Reminiscence Functions Scale, Les Cahiers Internationaux de Psychologie Sociale, 71, 3-14.

Miraux J.-P. (2005), L'autobiographie, écriture de soi et sincérité, Paris, Armand Colin.

Pineau G. et Le Grand J.-L. (1993), Les histoires de vie, Paris, PUF. 
Podaskoff P.M., MacKenzie S.B., Podaskoff N.P et Lee J.Y (2003), The mismeasure of man(agement) and its implications for leadership research, Leadership Quarterly, 14, 615-656.

Préel B. (2000), Le choc des générations, Paris, La Découverte.

Price L.L., Arnould E.J. et Curasi C.F. (2000), Older consumers' disposition of special possessions, Journal of Consumer Research, 27, 2, 179-201.

Pudal B. (2000), Écritures non professionnelles et prises de parole, Les Actes de Lecture, 69, 93-96.

Ribes G., Sagne A., Gaucher J. et Ploton L. (2009), Mémoire générationnelle et identité, Gérontologie et Société, 130, 145-153.

Rioul R. (2003), Le désir autobiographique, Conférence prononcée le 7 mars dans le cadre de l’Université du Temps Libre, Université Marc-Bloch, Strasbourg le 7 mars accessible sur le site de l'association pour l'autobiographie (http://www.sitapa.org)

Roche A. (2007), Le modèle autobiographique est-il exportable? Exemples au Maghreb, in F. Simonet-Tenant (coord.), Le propre de l'écriture de soi, Paris, Tétraèdre, 156-164.

Ross H.K. (1990), Lesson of life, Geriatric Nursing, 11, 274-275.

Rossiter J.R. (2002), The C-OAR-SE procedure for scale development in marketing, International Journal of Research in Marketing, 19, 305-335.

Satorra A. et Bentler P.M. (1988), Scaling corrections for chi square statistics in covariance structure analysis, Actes de la conférence annuelle de l'American Statistical Association, New Orleans, 308-313.

Steenkamp J.B. et Van Trijp H.C. (1991), The use of LISREL in validating Marketing construct, International Journal of Research in Marketing, 8, 283-289.

Tarman V.I. (1988), Autobiography: the negotiation of a lifetime, International Journal of Aging and Human Development, 27, 3, 171-191.

Trueman I. et Parker J. (2006), Exploring community nurses' perceptions of life review in palliative care, Journal of Clinical Nursing, 15, 197-207.

Urien B. (2003), L'anxiété face à la mort et son influence sur le comportement du consommateur, Recherche et Applications en Marketing, 18, 4, 23-41.

Urien B. et Guiot D. (2007), Attitude face à la mort et comportement d'ajustement des consommateurs âgés : Vers l'élaboration d'une réponse marketing, Décisions Marketing, 46, 23-35. 
Urien B. et Kilbourne W. (2007), Generativity and its relationship to eco-friendly consumption behavior, Actes de la Conférence de l'American Marketing Association (AMA), San Diego, Californie, USA.

Urien B. et Kilbourne W. (2011), On the role of generativity and self-enhancement values in eco-friendly behavioural intentions and environmentally responsible consumption behaviour, Psychology and Marketing, 28, 1, 69-90

Vallerand R.J (1997), Toward a hierarchical model of intrinsic and extrinsic motivation, in M.P. Zanna (coord.), Advances in experimental social psychology, 29, 271-360, New York: Academic Press.

Vallerand R.J. (2000), Deci and Ryan's self-determination theory: A view from the hierarchical model of intrinsic and extrinsic motivation. Psychological Inquiry, 11, 312 318.

Vallerand, R.J. et Miquelon P. (2009), Le modèle hiérarchique : Une analyse intégrative des déterminants et conséquences de la motivation intrinsèque et extrinsèque, in R.-V. Joule (coord.), Bilans et perspectives en psychologie sociale, Grenoble, Presses de l'Université de Grenoble.

Vercauteren R. et Hervy B. (2003), L'animation dans les établissements pour personnes âgées, Manuel des pratiques professionnelles, Pratiques gérontologiques, Paris, Eres.

Wallendorf M. et Arnould E.J. (1988), "My favourite things": a cross-cultural inquiry into object attachment, possessiveness, and social linkage, Journal of Consumer Research, $14,4,531-547$.

Wapner S., Dermick J. et Redondo J.P. (1990), Cherished possessions and adaptation of older people to nursing homes, International Journal of Aging and Human Development, 31, $3,219-236$.

Webster J.D. (1993), Construction and validation of the reminiscence function scale, Journal of Gerontology: Psychological Sciences, 48, 256-262.

Wilcox J.B., Howell R.D. et Breivik E. (2008), Questions about formative measurement, Journal of Business Research, 61, 1219-1228.

Zanone D. (2006), L'autobiographie, Paris, Ellipses

Zarca B. (2009), Triple démarche pour une transformation de soi. Psychanalyse, socioanalyse et autobiographie, Le Coq-Héron, 198, 118-130.

Zemke R., Raines C. et Filipczak B. (2000), Generations at work: managing the clash of veterans, boomers, Xers and nexers in your workplace, New York: Amacom 


\section{Appendix A1: Items generated by the authors and selected by the experts}

The following table presents the items generated and selected by the experts.

-The number corresponds to the position of the statement on the scale. For example, the item "to tell my family and friends what I would like to be remembered for" within the dimension being remembered was administered in the $15^{\text {th }}$ and $8^{\text {th }}$ place, respectively, when collecting the two data sets.

-The mention "E" indicates an item that was eliminated after PCA.

-Items marked with an asterisk $(*)$ were generated and administered during collection of the second data set.

\begin{tabular}{|c|c|c|c|}
\hline I would like to write my life story... & \multicolumn{2}{|c|}{$1^{\text {st }}$ data set } & $2^{\text {nd }}$ data set \\
\hline \multicolumn{4}{|l|}{ Being remembered } \\
\hline so I can highlight the things I would like to be remembered for & 30 & $\mathrm{E}$ & \\
\hline in order to choose what I would like to leave for posterity & 17 & E & \\
\hline $\begin{array}{l}\text { because it is important for me to know how my family and friends will remember me } \\
\text { after my death }\end{array}$ & 9 & $\mathrm{E}$ & \\
\hline to tell my family and friends what I would like to be remembered for & 15 & & 8 \\
\hline $\begin{array}{l}\text { because I believe leaving something behind is a way to achieve a form of } \\
\text { immortality }\end{array}$ & 6 & $\mathrm{E}$ & \\
\hline so my family and friends remember me after my death & 34 & & 4 \\
\hline because writing about one's life is a way of being remembered & 12 & E & \\
\hline so that people will remember what I have done after my death & 20 & & 12 \\
\hline \multicolumn{4}{|l|}{ Bearing witness } \\
\hline to help future generations understand how the world has changed & 27 & $\mathrm{E}$ & \\
\hline $\begin{array}{l}\text { to leave a trace of the way we lived, so that future generations can picture our way of } \\
\text { life }\end{array}$ & 3 & & 5 \\
\hline $\begin{array}{l}\text { to leave a testimonial, because it is a sort of heritage you pass on to future } \\
\text { generations }\end{array}$ & 13 & & 9 \\
\hline $\begin{array}{l}\text { because I think that expressing our thoughts about society can enable future } \\
\text { generations to understand the world in which they will live }\end{array}$ & 29 & $\mathrm{E}$ & \\
\hline because leaving behind an account of our times is like a gift for future generations & 31 & $\mathrm{E}$ & \\
\hline $\begin{array}{l}\text { because there are certain things that should be preserved and transmitted from one } \\
\text { generation to another }\end{array}$ & 33 & $\mathrm{E}$ & \\
\hline to preserve certain aspects of my culture that are disappearing & 24 & & 13 \\
\hline because we need make sure some things are not forgotten & 4 & $\mathrm{E}$ & \\
\hline to record, somewhere, certain things that must not be lost & 18 & & 16 \\
\hline \multicolumn{4}{|l|}{ Sharing } \\
\hline to create a certain intimacy with readers & 19 & & 6 \\
\hline to broaden my circle of acquaintances & 2 & & 10 \\
\hline to create ties with certain people & 14 & & 14 \\
\hline $\begin{array}{l}\text { because it is important to talk about life's difficulties, to show people who are going } \\
\text { through the same things that they are not alone }\end{array}$ & 16 & $\mathrm{E}$ & \\
\hline \multicolumn{4}{|l|}{ Mending the ego } \\
\hline to help me clarify a period in my life & 7 & & 3 \\
\hline to tell my side of the story concerning certain things that happened in the past & 32 & & 7 \\
\hline
\end{tabular}




\begin{tabular}{|c|c|c|c|c|}
\hline to tell the truth about certain things that happened in the past & 8 & & 11 & \\
\hline to justify certain things I did in the past & 11 & & 15 & \\
\hline to confess to certain things & 35 & $\mathrm{E}$ & & \\
\hline because I want to talk about certain things that are important to me & 26 & $\mathrm{E}$ & & \\
\hline \multicolumn{5}{|l|}{ Flattering the ego } \\
\hline because there are things about my life that are worth knowing & 1 & $\mathrm{E}$ & & \\
\hline to show how I became the person I am today & 28 & $\mathrm{E}$ & & \\
\hline to talk about myself and the things I have done in my life & 22 & $\mathrm{E}$ & & \\
\hline because there are things I have done that should be recognized & 36 & $\mathrm{E}$ & & \\
\hline to talk about the interesting things I have done in my life & & & 2 & \\
\hline *to highlight things I have done and am proud of & & & 17 & \\
\hline *to highlight things about myself that others are not necessarily aware of & & & 19 & \\
\hline *to show people who don't know me who I really am & & & 21 & $\mathrm{E}$ \\
\hline *to show how I started out and how I became the person I am today & & & 22 & $\mathrm{E}$ \\
\hline \multicolumn{5}{|l|}{ Transmitting } \\
\hline to prevent the younger generation from making the same mistakes as I did & 21 & $\mathrm{E}$ & & \\
\hline to transmit certain essential values to the younger generation & 10 & $\mathrm{E}$ & & \\
\hline to show the younger generation their roots & 23 & $\mathrm{E}$ & & \\
\hline by transmitting my life story and experiences, I am trying to help others & 5 & $\mathrm{E}$ & & \\
\hline $\begin{array}{l}\text { because I want the younger generation to understand what one should, or should not, } \\
\text { do }\end{array}$ & 25 & $\mathrm{E}$ & & \\
\hline *to retrace my family history & & & 1 & $\mathrm{E}$ \\
\hline *to tell the younger generation about family members who have passed away & & & 18 & \\
\hline *to transmit family values & & & 20 & \\
\hline$*$ for the younger members of the family who want to know about their roots & & & 23 & \\
\hline
\end{tabular}


Appendix A2: Socio-demographic characteristics of the quantitative data

\begin{tabular}{|l|c|c|}
\hline & $\begin{array}{c}1^{\text {st }} \text { data set } \\
202 \text { individuals }\end{array}$ & $\begin{array}{c}2^{\text {nd }} \text { data set } \\
508 \text { individuals }\end{array}$ \\
\hline Age & & 68.80 \\
\hline Average age & 71.28 & 6.84 \\
\hline Standard deviation & 8.60 & 60 \\
\hline Minimum & 60 & 94 \\
\hline Maximum & 96 & $36 \%$ \\
\hline Gender & $44 \%$ & $64 \%$ \\
\hline Men & $56 \%$ & $8.7 \%$ \\
\hline Women & & $22.1 \%$ \\
\hline Level of education & $22.8 \%$ & $13 \%$ \\
\hline No diploma & $25.4 \%$ & $22.7 \%$ \\
\hline $\begin{array}{l}\text { Secondary school certificate } \\
\text { (11-13 years) }\end{array}$ & $10.9 \%$ & $19.7 \%$ \\
\hline $\begin{array}{l}\text { Vocational degree } \\
\text { School level) }\end{array}$ & $11.4 \%$ & $13.8 \%$ \\
\hline $\begin{array}{l}\text { Baccalaureate (High School) } \\
\text { level }\end{array}$ & $12.4 \%$ & $12.2 \%$ \\
\hline 1 to 3 years college & $17.1 \%$ & $12 \%$ \\
\hline Bachelor degree or higher & & $73.8 \%$ \\
\hline Number of children & $3.1 \%$ & $2 \%$ \\
\hline No children & $13.9 \%$ & \\
\hline 1 child & $72.7 \%$ & \\
\hline 2 to 4 children & $10.3 \%$ & \\
\hline 5 or more children & & \\
\hline
\end{tabular}




\section{Appendix A3: Scale of motivations for legacy writing among the elderly}

\section{Instructions:}

Legacy writing consists in using your memories to write your life story. Please indicate if the following statements concern you or not (strongly disagree, disagree, neither agree nor disagree, agree, strongly agree).

\section{I would like to write my life story...}

\section{Being remembered $(\alpha=\mathbf{0 . 8 3})$}

so my family and friends remember me after my death

to tell my family and friends what I would like to be remembered for

so that people will remember what I have done after my death

\section{Bearing witness $(\alpha=\mathbf{0 . 8 3})$}

to leave a trace of the way we lived, so that future generations can picture our way of life to leave a testimonial, because it is a sort of heritage you pass on to future generations

to preserve certain aspects of my culture that are disappearing

to record, somewhere, certain things that must not be lost

\section{Sharing $(\alpha=0.79)$}

to create a certain intimacy with readers

to broaden my circle of acquaintances

to create ties with certain people

\section{Mending the ego $(\alpha=0.81)$}

to help me clarify a period in my life

to tell my side of the story concerning certain things that happened in the past

to tell the truth about certain things that happened in the past

to justify certain things I did in the past

\section{Flattering the ego $(\alpha=0.80)$}

to talk about the interesting things I have done in my life

to highlight things I have done and am proud of

to highlight things about myself that others are not necessarily aware of

Transmitting ( $\alpha=0.81)$

to tell the younger generation about family members who have passed away to transmit family values

for the younger members of the family who want to know about their roots 
Table 1 - The stages involved in constructing and validating the measurement scale

\begin{tabular}{|c|c|}
\hline Stages performed & Key results \\
\hline $\begin{array}{l}\text { 1- Specifying the } \\
\text { construct's field }\end{array}$ & $\begin{array}{l}\text {-There are } 6 \text { motivations behind legacy writing, identified in the } \\
\text { literature and confirmed during a qualitative analysis (not developed } \\
\text { here) } \\
\text {-These indicators are effects of the construct. Churchill's paradigm } \\
\text { is adapted }\end{array}$ \\
\hline $\begin{array}{l}\text { 2- Creating and } \\
\text { validating items }\end{array}$ & $\begin{array}{l}\text { - } 16 \text { semi-structured interviews (not developed here) } \\
-77 \text { items generated based on the literature and qualitative } \\
\text { interviews } \\
-36 \text { items selected by a panel of experts (face validity) }\end{array}$ \\
\hline $\begin{array}{l}\text { 3- Collecting the first } \\
\text { data set and purifying the } \\
\text { items }\end{array}$ & $\begin{array}{l}\text { - } 202 \text { responses } \\
\text { - } 22 \text { items eliminated through } 6 \text { PCA (oblique rotation) } \\
\text { - The dimensions transmitting and flattering the ego do not emerge: } \\
9 \text { new items are generated representing these dimensions }\end{array}$ \\
\hline $\begin{array}{l}\text { 4- The second data set } \\
\text { and the emergence of the } \\
\text { factor structure }\end{array}$ & $\begin{array}{l}\text { - } 508 \text { responses } \\
\text { - } 3 \text { items eliminated through } 3 \text { PCA } \\
\text { - } 20 \text { items cluster around } 6 \text { dimensions: Flattering the ego }(\alpha= \\
0.80) \text {; mending the ego }(\alpha=0.81) \text {; being remembered }(\alpha=0.83) ; \\
\text { sharing }(\alpha=0.79) \text {; transmitting }(\alpha=0.81) \text { and bearing witness }(\alpha= \\
0.83)\end{array}$ \\
\hline $\begin{array}{l}\text { 5- Validating the factor } \\
\text { structure }\end{array}$ & $\begin{array}{l}\text { - Confirmatory factor analysis } \\
\text { - Parameters estimated with ML (Maximum Likelihood)). "Robust" } \\
\text { statistics corrected for non-normality } \\
-\chi^{2}=340 ; \mathrm{df}=155(\mathrm{p}=0.00) ; \mathrm{CFI}=0.95 ; \mathrm{RMSEA}=0.05 \\
\text { - All the alternative models tested produce less satisfactory fit } \\
\text { indices } \\
\text { - Factor structure confirmed }\end{array}$ \\
\hline $\begin{array}{l}\text { 6- Reliability, } \\
\text { convergent and } \\
\text { discriminant validities of } \\
\text { the measurement model }\end{array}$ & $\begin{array}{l}- \text { All } \rho>0.80 \text { (reliability) } \\
\text {-Structural coefficients significantly linked (z-test }>1.96) \text { and } \rho_{\mathrm{vc}}> \\
0.5 \text { (convergent validity) } \\
\text {-The correlations between the two constructs squared are less than } \\
\text { their } \rho_{\mathrm{vc}} \text { (discriminant validity) }\end{array}$ \\
\hline $\begin{array}{l}\text { 7- Second-order factor } \\
\text { analysis and nomological } \\
\text { validity }\end{array}$ & $\begin{array}{l}\text { - Existence of a second-order factor }\left(\chi^{2}=381 ; \text { dof }=164(\mathrm{p}=0.00) \text {; }\right. \\
\text { CFI }=0.95 ; \text { RMSEA }=0.05) \text {; structural coefs }>0.70 ; \text { representing } \\
\text { the "global" motivation for legacy writing } \\
\text { - The correlation between this global motivation and the real } \\
\text { intention to write a life story is } 0.5 \text { (nomological validity) }\end{array}$ \\
\hline
\end{tabular}


Table 2 - Final factor structure of the 20 items

\begin{tabular}{|c|c|c|c|c|c|c|c|c|}
\hline & & & & & & & \\
\hline & & Communality & Factor 1 & Factor 2 & Factor 3 & Factor 4 & Factor 5 & Factor 6 \\
\hline $\begin{array}{l}\text { Being } \\
\text { remembered } \\
(\alpha=\mathbf{0 , 8 3})\end{array}$ & $\begin{array}{l}\text { so my family and friends remember me after my death } \\
\text { to tell my family and friends what I would like to be remembered for } \\
\text { so I will be remembered after my death }\end{array}$ & $\begin{array}{l}0.72 \\
0.71 \\
0.79\end{array}$ & $\begin{array}{l}0.77 \\
0.69 \\
0.82\end{array}$ & & & & & \\
\hline $\begin{array}{c}\text { Bearing witness } \\
(\alpha=0.83)\end{array}$ & $\begin{array}{l}\text { to leave a trace of the way we lived, so that future generations can picture our way } \\
\text { of life } \\
\text { to leave a testimonial, because it is a sort of heritage you pass on to future } \\
\text { generations } \\
\text { to preserve certain aspects of my culture that are disappearing } \\
\text { to record, somewhere, certain things that must not be lost }\end{array}$ & $\begin{array}{l}0.70 \\
0.74 \\
0.63 \\
0.66\end{array}$ & & $\begin{array}{l}0.71 \\
0.79 \\
0.60 \\
0.70\end{array}$ & & & & \\
\hline $\begin{array}{c}\text { Sharing }(\alpha= \\
0.79)\end{array}$ & $\begin{array}{l}\text { to create a certain intimacy with readers } \\
\text { to broaden my circle of acquaintances } \\
\text { to create ties with certain people }\end{array}$ & $\begin{array}{l}0.65 \\
0.73 \\
0.74\end{array}$ & & & $\begin{array}{l}0.72 \\
0.81 \\
0.86 \\
\end{array}$ & & & \\
\hline $\begin{array}{l}\text { Mending the } \\
\text { ego }(\alpha=0.81)\end{array}$ & $\begin{array}{l}\text { to help me clarify a period in my life } \\
\text { to tell my side of the story concerning certain things that happened in the past } \\
\text { to tell the truth about certain things that happened in the past } \\
\text { to justify certain things I did in the past }\end{array}$ & $\begin{array}{l}0.58 \\
0.72 \\
0.74 \\
0.67\end{array}$ & & & & $\begin{array}{l}0.68 \\
0.75 \\
0.81 \\
0.64\end{array}$ & & \\
\hline $\begin{array}{l}\text { Flattering the } \\
\text { ego }(\alpha=0,80)\end{array}$ & $\begin{array}{l}\text { to talk about the interesting things I have done in my life } \\
\text { to highlight things I have done and am proud of } \\
\text { to highlight things about myself that others are not necessarily aware of }\end{array}$ & $\begin{array}{l}0.72 \\
0.79 \\
0.71\end{array}$ & & & & & $\begin{array}{l}0.82 \\
0.75 \\
0.58\end{array}$ & \\
\hline $\begin{array}{l}\text { Transmitting } \\
\quad(\alpha=0,81)\end{array}$ & $\begin{array}{l}\text { to tell the younger generation about family members who have passed away } \\
\text { to transmit family values } \\
\text { for the younger members of the family who want to know about their roots }\end{array}$ & $\begin{array}{l}0.74 \\
0.75 \\
0.76\end{array}$ & & & & & & $\begin{array}{l}0.86 \\
0.83 \\
0.82\end{array}$ \\
\hline & $\begin{array}{c}\text { Eigenvalue } \\
\text { of }\end{array}$ & & $\frac{8.2}{41 \%}$ & 1.74 & $\frac{1.24}{6 \%}$ & $\frac{1.10}{5.0}$ & 1.07 & 0.93 \\
\hline
\end{tabular}


Table 3 - Evaluation of reliability and convergent validity

\begin{tabular}{|c|c|c|c|}
\cline { 2 - 4 } \multicolumn{1}{c|}{} & Reliability & \multicolumn{2}{|c|}{ Convergent validity } \\
\hline Dimensions & $\rho$ & $\mathrm{z}$-tests & $\rho_{\mathrm{vc}}$ \\
\hline Being remembered & 0.82 & $\mathrm{z}>20$ & 0.63 \\
\hline Bearing witness & 0.84 & $\mathrm{z}>16$ & 0.57 \\
\hline Sharing & 0.80 & $\mathrm{z}>16$ & 0.57 \\
\hline Mending the ego & 0.82 & $\mathrm{z}>13$ & 0.53 \\
\hline Flattering the ego & 0.81 & $\mathrm{z}>13$ & 0.59 \\
\hline Transmitting & 0.83 & $\mathrm{z}>16$ & 0.61 \\
\hline
\end{tabular}


Table 4 - Evaluation of discriminant validity and correlations between constructs

\begin{tabular}{|l|c|c|c|c|c|c|}
\hline & $\begin{array}{c}\text { Being } \\
\text { remembered }\end{array}$ & $\begin{array}{c}\text { Bearing } \\
\text { witness }\end{array}$ & Sharing & $\begin{array}{c}\text { Mending } \\
\text { the ego }\end{array}$ & $\begin{array}{c}\text { Flattering } \\
\text { the ego }\end{array}$ & Transmitting \\
\hline Being remembered & 0.79 & & & & & \\
\hline Bearing witness & 0.67 & 0.75 & & & & \\
\hline Sharing & 0.62 & 0.63 & 0.75 & & & \\
\hline Mending the ego & 0.70 & 0.56 & 0.65 & 0.73 & & \\
\hline Flattering the ego & 0.69 & 0.54 & 0.62 & 0.69 & 0.77 & \\
\hline Transmitting & 0.58 & 0.69 & 0.50 & 0.55 & 0.51 & 0.78 \\
\hline
\end{tabular}


Table 5 - Second-order factor analysis

\begin{tabular}{|c|c|}
\hline First-order factors & $\begin{array}{c}\text { Loadings } \\
\text { (standardized) }\end{array}$ \\
\hline Being remembered & 0.853 \\
\hline Bearing witness & 0.780 \\
\hline Sharing & 0.768 \\
\hline Mending the ego & 0.813 \\
\hline Flattering the ego & 0.779 \\
\hline Transmitting & 0.713 \\
\hline
\end{tabular}

